\title{
YALE
}

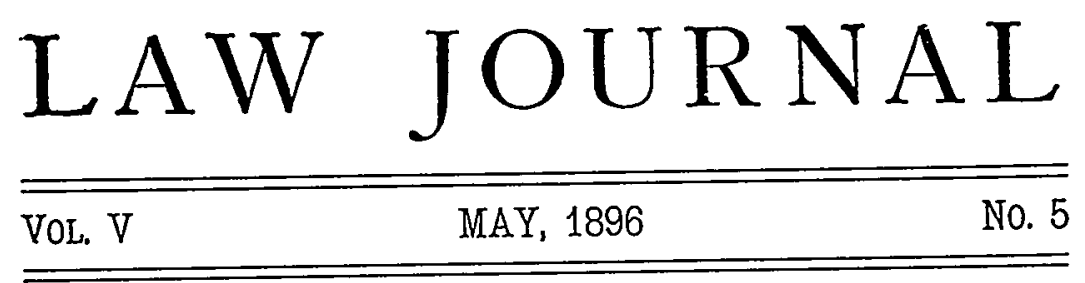

\section{TAKING CORPORATE SHARES BY RIGHT OF EMINENT DOMAIN.}

The last legislature of the State of Connecticut enacted a statute which by its terms enables any railroad company which shall be the owner of more than three-fourths of the stock of any steamboat, ferry, bridge, wharf or railroad company, to acquire by condemnation the shares of other stockholders. The statute is quoted in full in the margin. ${ }^{1}$

1 Public Acts, I895. Chap. ccxxxii.

"Section I. In case any railroad company acting under the authority of the laws of this state shall have acquired more than three-fourths of the capital stock of any steamboat company, ferry company, bridge company, wharf company, or railroad company, and cannot agree with the holders of outstanding stock for the purchase of the same, upon a finding by a judge of the superior court that such purchase will be for public interest, it may cause such outstanding stock to be appraised in the manner provided by section 3464 of the general statutes; and when said appraisement shall have been paid or deposited as provided in said section, the stockholder or stockholders whose share or shares shall have been so appraised shall cease to have any interest therein, and shall on demand made, surrender said stock and all certificates thereof to the corporation applying for such appraisal, and upon the deposit of said appraisal said certificates shall be deemed to be cancelled.

Section 2. "Any person holding a minority of the shares of stock in any company described in section one of this act may, if he cannot agree with the corporation owning three-fourths of such stock for the purchase of his shares, cause the same to be appraised in the manner provided by section one of this act; and an appraisement having been made and recorded in the office of the clerk of the superior court of any county where such railroad company operates a railroad, shall operate as a judgment against such company and in favor of the holder of such stock, and at the end of sixty days, unless such judgment is paid, execution may be issued.

(Section 3464 of general statutes provides for appraisal of land needed for railroad purposes.) 
This statute is cited as a remarkable and extreme example of one method of effecting corporate consolidations. It is not known to the writer whether the aid of the courts has been asked to enforce its provisions, but it can readily be seen that in such case there might arise important questions. The statute suggests especially a consideration of the exercise of the right of eminent domain upon the interests of a shareholder in a corporation,- the conditions which lead to the exercise of the power, and the propriety of its exercise by the legislature.

The corporation, a legal entity distinct from its members, is the owner of all the corporate property and franchises. There always exists in the State a right to take such property and franchises for a public use, compensation for which having been paid to the corporation, the right of each shareholder in what has been so taken is completely extinguished, and there remains no necessity for any proceeding against the individual shareholder. Action against the corporation direct is always adopted unless it happens that holders of a majority of the stock are willing to transfer the corporate property without compelling the taker to proceed by condemnation. Practically, therefore, condemnation of corporate shares will never be attempted except as against a dissenting minority in cases where an extension of the corporate business or a consolidation is contemplated by the majority. It is clear that, if the majority had power to compel the retirement of a minority holder upon payment to him of the value of his shares, there would exist no occasion for a resort to taking of such shares by eminent domain. As will be seen, the majority have asserted such power in rare instances independently of the right of eminent domain, but the authority of those cases is doubtful.

I. A shareholder cannot be compelled by the majority to join with them in a fundamental alteration of the corporate business, such as a consolidation. ${ }^{2}$ This is familiar law, but it may be well to briefly state the reasons upon which it is based.

A corporation may exercise only those powers which are granted to it by the State. This limitation of its powers governs not only the relation of the corporation to the State, but also the relation of the corporation to its shareholders and of the shareholders to one another. Every holder of stock, whether acquired by subscription or by transfer, is a party to a contract by which he is bound to allow the common property to be man-

2 Thompson, Comm. on law of Corporations, Sec. 343; Clearwater v. Meredith, I Wall. 25; Morawetz, Private Corporations, 2d Ed., Secs. 395, 396; Beach, Private Corporations, Sec. 353. 
aged, controlled and applied in the pursuit of the corporate purposes as expressed in the charter, by agents selected by the majority. He parts with the right to individually manage, possess and control such property except through the exercise of his voting power. But the power of the majority and of the corporate officers over the property of the shareholders is strictly limited to the purposes of the corporation as expressed in the charter. ${ }^{3}$ A fundamental departure from the original corporate undertaking is a wrong which the shareholder may resist and prevent.

But a shareholder may not hold his fellow members to the continuance of an unprofitable business. For just cause the majority may abandon the enterprise, dispose of the corporate property and distribute the net proceeds among the shareholders. ${ }^{*}$ In such case, however, it is the right of the shareholder to have the value of the corporate property ascertained by an actual and bona fide sale. ${ }^{5}$ Except as incidental to such an abandonment of the enterprise, a transfer of the corporate property and business to another person or corporation may not be made without the consent of every shareholder.

II. May the majority effect such a fundamental alteration against the consent of a shareholder upon furnishing him sccurity against loss?

In Lauman $v$. Lebanon Valley R. R. Co., 30 Pa. St. 42 ( $185^{8}$ ), application was made by a stockholder of the defendant company for an injunction to restrain it from consummating a proposed merger of that company into the Philadelphia \& Reading R. R. Co. The merger was authorized by legislative act to take effect on approval by a majority of the stockholders of each corporation, the holders of stock in the defendant company to surrender the same and receive shares of stock in the Reading Company. No provision was made in the act or in the agreement for the case of any member of the defendant company who might not be willing to make the exchange.

The court holds that plaintiff could not be compelled to accept shares of the Reading Company in the place of his interest in the defendant company, but orders that the injunction asked for be granted only until the plaintiff be given security for the value of his stock. In Stevens v. Rutland \& B. R. R. Company, $29 \mathrm{Vt}$.

${ }^{3}$ Durfee v. Old Colony, etc. R. R., 5 Allen 230; Byrne v. Schuyler E1. Mfg. Co., 65 Conn. 336.

1 Price $v$. Holcomb, 89 Iowa 123.

- Mfason $v$. Pewabic Mining Co., 133 U. S. 50; Thompson, Comm. on Law of Corporations, Sec. 35I; Taylor $v$. Earle, 8 Hun. I. 
545 ( $185 \mathrm{r}$ ), after an exhaustive examination of the law and authorities the Chancellor grants an injunction restraining the defendant railroad from making an extension authorized by the legislature and accepted by vote of the majority stockholders, but not authorized by the original charter. Before the injunction issued it was proposed to file bonds to indemnify the plaintiff, but the Chancellor suggested that he did not deem it competent for him to make contracts for the parties. The Chancellor cited Natusch $v$. Irving, 2 Cooper Ch. $35^{8}$, a case in which Lord Eldon had granted an injunction against an unauthorized extension of the business of a voluntary association at the suit of a dissenting member, although it was proposed to indemnify the plaintiff.

The decision in Lauman $v$. R. R., that the consolidation might be effected if plaintiff was secured from loss, has been criticised, ${ }^{6}$ and the decision of the Chancellor in Stevens v. R. R. seems to be better law. It is not consistent with the contract of membership that the majority holders should have power to obtain from the legislature an alteration of the corporate undertaking and then compel a dissenting holder to accept their terms or retire from the enterprise. In the language of Lord Eldon, "the right of a partner is to hold to the specified purposes his partners whilst the partnership continues, and not to rest upon indemnities with respect to what he has not contracted to engage in."

In the cases cited no provision had been made by the legislature for the valuation and extinction of a dissenting shareholder's interest. Since, however, the power of the majority is determined by the contract relation of the shareholders, no legislative act after the contract is concluded can enlarge that power. In a New Jersey case such legislative provision was made but it was treated by counsel and the court as an exercise of the right of eminent domain, and is discussed infra. ${ }^{7}$

It appears, therefore, that there is no recognized right in the majority holders to extinguish the rights and voice of a dissenting minority by taking their shares at a valuation.

III. The pozeer of the majority as affected by a reserved right of amendment and repeal.

Statutory provisions, in force at the time of the stock subscription, authorizing consolidation upon vote of the majority holders,

6 Black v. Dela. etc. Canal Co., 22 N. J. Eq. r30, see p. 405; Mowrey v. Ind. R. R., 4 Bissell U. S. 78; Federal Cases, No. 989I; Thompson, Comm. on law of Corporations, Secs. 343, 351 .

' Black v. Dela. etc. Canal Co., 24 N. J. Eq. 455. 
are a part of the contract of membership. Such statutes have sometimes provided for the appraisal of the shares of a dissenting holder. But a difficult question arises where there is merely a constitutional or legislative reservation of power to amend, alter or repeal the charter of the corporation, and by a subsequent amendment or general law the legislature authorizes an extension of the corporate business or a consolidation.

Several cases have held that, where such power of amendment is reserved, an enlargement of the corporate undertaking by legislative authority, if it does not constitute a fundamental alteration, will not discharge a subscriber to the stock. ${ }^{8}$ Two courts, those of Massachusetts ${ }^{9}$ and Connecticut, ${ }^{10}$ have gone further and declared that a consolidation may be effected against the consent of the minority stockholders if a general power of amendment has been reserved. But they cannot be regarded as concluding the question, since it might be decided contra by courts which take the position that such power is reserved for the protection of the public interests, and concerns the contract between the State and the corporation, not that between the shareholders. ${ }^{\text {"I }}$ If the latter be the correct view, it follows that under such reserved power of amendment the legislature cannot provide for the appraisal and extinction of shares of a dissenting holder. The contract which protects him from being unwillingly carried into a new venture will equally protect him from being unwillingly driven out of the old.

IV. The right of eminent domain.

In this situation of the law it has been suggested that the share of a dissenting stockholder may in certain cases be extinguished by condemnation.

Several eminent text-writers apparently endorse this suggestion. ${ }^{12}$ Their statements are based on a single case as authority: Black v. Delaware \& Raritan Canal Co. et al, 24 N. J. Eq. 455 (reversing Black v. Dela. etc. Co., 22 N. J. Eq. 130; 1871). In this case a stockholder of defendant companies sought to restrain

${ }^{8}$ See Buffalo, etc. R. R. v. Dudley, I4 N. Y. 336 .

9 Hale v. Cheshire R. R. Co., r6I Mass. 443; Durfee v. Old Colony, etc. k. R., 5 Allen 230.

${ }^{10}$ Bishop $v$. Brainerd, 28 Conn. 289.

"See Thompson, Comm. on law of Corporations, Secs. 90, 9r, 347; Oldtown R. R. v. Veazie, 39 Me. 57I; Green's Brice's Ultra Vires, pp. 98, 99, note; Mowry v. Ind. \& C. R. Co., 4 Bissell U. S. 78; Fed. Cases, No. 989I.

13 Cook on Stock and Stockholders, 3d Ed., Sec. 896; Morawetz, Private Corporations, 2d Ed., Sec. 1089; Beach, Private Corporations, Sec. 355; Green's Brice's Ultra Vires, p. 99, note. 
them from executing a lease of their property and franchises to the Pennsylvania R. R. Company. The statute under which the right to execute such lease was claimed provided that the contract should be effected upon approval of two-thirds of the stockholders in each corporation, and that upon such approval any shareholder refusing to accept the terms of the contract should be paid the full value of his stock. The Chancellor denied the injunction, but his decree was reversed on appeal. Although the decision was placed expressly upon other grounds, the appellate court discusses the provisions of the statute referred to, and announces the principle that the shares of a dissenting holder may be so taken by eminent domain. The court based its declaration solely upon the well settled principle that corporate franchises are not exempt from condemnation, both the Chancellor and the appellate court conciurring in the opinion that the act in question was constitutional.

It cannot be claimed that corporate shares are exempt from the exercise of the right of eminent domain, for all property is subject to the paramount necessities of the State and the public interest. But a consideration of the nature of corporate shares as property and of the conditions under which the right may be claimed, proves that there is but little occasion, if any, for the exercise of such right, while the propriety of its exercise in any instance may be seriously questioned.

While some authorities hold that it is within the power of the courts to decide in any instance whether the use for which the power is claimed is such as to justify its exercise, yet the power is political, belonging to the legislature, which must determine the necessity, the manner and the extent of its exercise. Yet the legislature should be controlled by a due regard for the rights of private property, as well as for the public necessities. The right is based upon the necessities of the public interest.

The interest of a shareholder is a proportional right in both the property and franchises of a corporation. To take his share from him is to extinguish his interest in both. It should not therefore be taken from him unless it is necessary for the public use designated that every corporate franchise in which he has such interest, be acquired or extinguished. The interest, also, of the parties exercising the power demands that the stock be left undisturbed unless they desire such acquisition or extinction of the franchise.

A necessity can rarely, if ever, exist for acquiring or extinguishing the franchises of any other than a quasi-public corpora- 
tion, though it is possible that instances may occur where the franchise of a private business corporation might be so dependent upon special property for its value that to take such property would practically destroy the franchise. Except in some such rare instance, therefore, there could be no necessity and no desire to exercise the power unless for the acquisition or extinction of the active franchises of a quasi-public corporation. The property of such a corporation is already subject to a public use.

Unless it be proposed to subject the property to a use, public in its nature, not already within the charter powers of the corporation whose property is taken, the power of eminent domain should not be exercised. There can be no necessity or propriety in the taking, unless the rights of the public with reference to the property are to be enlarged. It is within the power of the State to enforce a full and satisfactory performance of its public duties by a quasi-public corporation. If such corporation fails in its duty, its charter may be forfeited, but its property and franchises may not be transferred to another. In this connection it is perfectly evident that the right of eminent domain cannot be exercised with propriety to enable the corporation itself, or a majority of its stockholders, to eliminate the interest of one or more shareholders, if the franchises of the corporation and its public duties are to remain unchanged. The State has no concern with the ownership of stock in a quasi-public corporation, whether it be in one person or another, for there can be no presumption that one shareholder will better than another perform the public service required through the corporate agencies. (If concerned at all, the State is interested that one quasi-public corporation should not own stock in another).

The Connecticut statute referred to enables the dominant holder to acquire by compulsory process any portion of the minority stock without any alteration in the corporate powers or duties. Although the stock so taken is directed by the statute to be cancelled, yet the taker is apparently left with power to dispose of the interest so acquired in such manner as it pleases. Some further act is necessary before the stock so taken can be regarded as taken for a public use.

This leads us to the vital objection to the exercise of the power in question, and that is, its indirection. Since the right will never be claimed except the majority holders desire to effect either an enlargement of the corporate powers or a transfer of the property and franchises, or a merger of one corporation with another, in either case it is clear that the real taking of the 
property for the new public use occurs at the time when the corporation acts, whether by acceptance of a new charter, by transfer, or by agreement of merger. One process is in invitum against the stockholders, the other, which is the real taking, is dependent upon the voluntary action of the majority.

The right of eminent domain is properly exercised when property is required for public use and cannot be obtained by agreement with the owner. But the owner has no choice as to whether he shall part with his property. The State does not concern itself with his willingness or unwillingness to yield possession. Any supposed exercise of the right of eminent domain which is grounded upon consent instead of upon necessity is wrongful. If corporate franchises and property are required for a new public use, the necessity is the same whether one or all the shareholders object. In the instance cited, of Lauman $v . R . R$. and Black $v$. Canal Company, the latter of which was expressly announced by the court as an exercise of the right of eminent domain, the very fact that the right of consolidation was dependent upon the consent of a majority of the stockholders is itself quite conclusive against its necessity.

Many consolidations and extensions have been effected in which provision has been made for the appraisal of the shares of a dissenting holder. Legislative enactments authorizing such action customarily provide that a minority holder shall have his election whether to receive the value of his shares or to accept the terms upon which the majority participate in the new undertaking. The Connecticut statute is unique in denying that privilege.

In some instances such consolidations and extensions may have been demanded by the public interest, but it is a matter of common knowledge that they are usually undertaken for the profit or advantage of majority holders and the dominant corporation. The minority holder is justly entitled to a continuance of the original corporate undertaking according to the terms of his contract, unless the public interest demands its termination. That question of public use and necessity he is entitled to have decided independently of the wishes or advantage of the majority holders. 